日臨外会誌 $66(12) ， 3024-3028 ， 2005$

症 例

\title{
卵巣様間質を伴った巨大な肝囊胞腺腫の 1 例
}

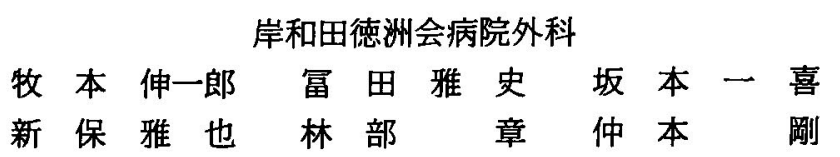

症例は35歳,女性。腹部膨満および腹痛にて紹介来院となった。腹部超音波, CT, MRI 検査にて肝内から肝外に著明に発育した最大径 $21 \mathrm{~cm}$ の巨大な多房性の豪胞性腫瘍が記 められた。肝動脈造影にて一部に濃染像を認め, 腫瘍マーカーでは CA19-9が247U/ml と 高值を示していた，肝哄胞腺腫あるいは腺癌の診断にて手術を施行した。晎胞は肝内の 中央 2 区域から肝外に著明に発育しており咅胞全体を含む肝部分切除術を施行した。摘 出標本では多房性宾胞で明らかな充実性部分は認めなかった. 組織学的には丵胞壁は一 層の粘液産生を示す円柱上皮で被覆され，上皮下の間質には卵巣間質類似の紡鍾形細胞 を認めた。悪性所見はなく, 卵巣様間質を伴った肝赛胞腺腫と診断した。術後 CA19-9は 正常化した．肝哄胞腺腫は比較的稀な疾患で術前に肝衰胞腺癌と鑑別するのは困難とさ れ，また悪性化の可能性もあり完全な害胞切除が必要である.

索引用語：肝宾胞腺腫, 卵巣様間質

\section{緒言}

肝亳胞腺腫は比較的稀な肝蒦胞性腫瘍であり女性に 多く, 肝堡胞腺癌への移行例も報告されているが要胞 完全切除により予後は良好とされている゙. 今回, 卵巣 様間質を伴う巨大な肝罴胞腺腫の 1 例を経験したので 報告する.

$$
\text { 症例 }
$$

患者：35歳，女性.

主訴：腹部膨満感, 腹痛.

既往歴：特記すへきことなし。

現病歴: 平成15年夏頃より腹部膨満感が出現し次第 に增強するようになり，腹痛も伴ってきたので近医を 受診し肝腫瘍との診断にて同12月 5 日紹介入院となっ た.

入院時現症：身長 $150 \mathrm{~cm}$, 体重 $52 \mathrm{~kg}$, 血圧 $83 / 64$ $\mathrm{mmHg}$, 脈拍数 $75 /$ 分. 眼瞼, 眼球結膜に賓血, 黄疸な し.上腹部は脚満しており圧痛を認めた。

入院時検査所見：血液生化学検查ではAST 45IU/ L, ALT 49IU/L と軽度上昇していた. 腫瘍マーカーで

2005年 7 月 1 日受付 2005年10月12日採用 〈所属施設住所〉

†596-8522 岸和田市加守町 4-27-1
は CEA は2.5ng/ml と正常であったがCA19-9は247 $\mathrm{U} / \mathrm{ml}$ と高值を示していた.

腹部超音波検査：肝内から肝外に著明に発育した多 房性の襄胞性病変があり,内部には混濁を認めた(図 1).

腹部造影 CT 検查：肝門部を中心に径 $21 \times 15 \mathrm{~cm}$ の 巨大な多房性の晎胞性腫瘤があり，造影される隔壁が 認められたが内腔に明らかな充実性部分はみられなか つた（图 2 a)．肝外に著明に発育し胃，膵は圧排され ており，胆襄は不明睹で同定できなかった（図 2 b) .

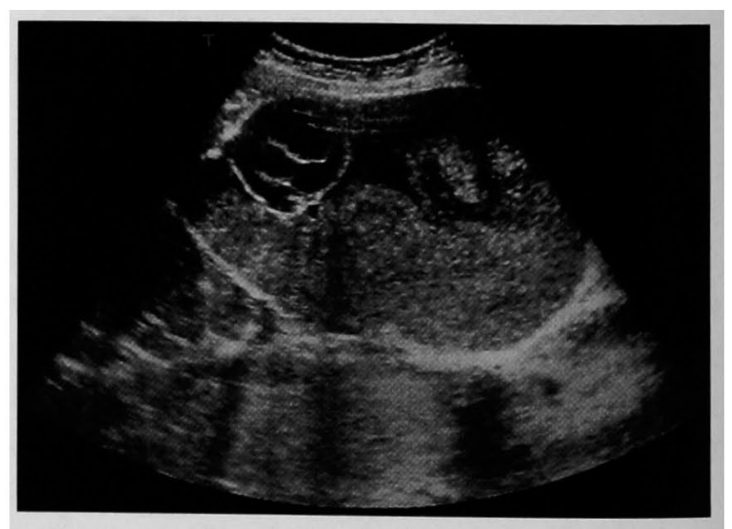

図 1 腹部超音波検査：肝内から肝外に著明に発育した 多房性の萑胞性病変があり，内部には混罣を認めた。 

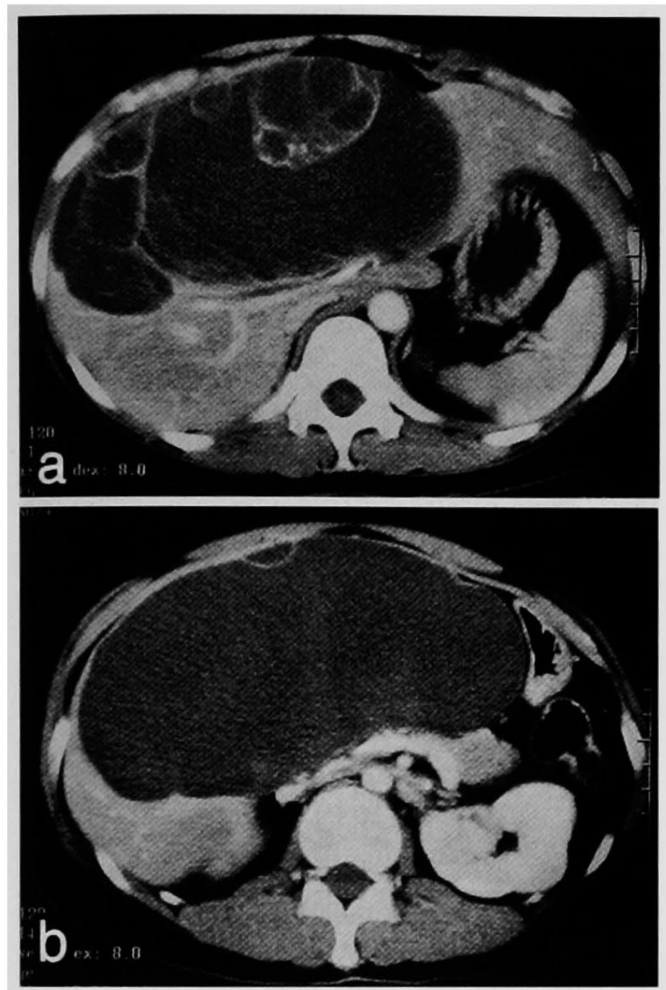

図 2 腹部造影 CT 検査：a ) 肝門部を中心に径 $21 \times$ $15 \mathrm{~cm}$ の巨大な多房性の衰胞性腫瘤を認めた。， b ) 咅胞性腫瘤は肝外に著明に発育し胃, 膵は圧排され ていた。

腹部 MRI 検査：肝門部を中心に最大径 $21 \mathrm{~cm}$ の多 房性の豪胞性腫瘤がみられ,肝実質は圧排されていた。 腫瘤内部は T1強調画像では低信号を呈し一部に高信 号を示す部位が認められ出血が疑われた(図 $3 \mathbf{a}$ ). T2 強調画像にて腫瘤内部は高信号を呈していた(図 3 b).

腹部血管造影：肝動脈造影では肝門部を中心に血流 の乏しい巨大な腫瘍がみられ肝実質は著明に圧排され て㧍り，腫湯の右外側辺緑部には径 $1.5 \mathrm{~cm}$ の濃染像が 認められ A8より分枝する動脈が栄養血管であった

(図 $4 \mathrm{a}$ ). 門脈の本幹, 左右の一次分枝は腫毫に圧排 され不明膫であった（図 4 b).

入院後も腹部鼔満感を強く訴え, 步行時にもかなり 制限を受けていた．画像所見では肝の多房性亯胞で明 らかな充実性部分は認められなかったが一部では出血 が疑われ，血管造影にて素胞内に濃染像が認められた ので肝蓄胞腺腫または腺癌の診断で同12月17日手術を 施行した.

手術所見：逆 T 字切開にて開腹した. 肝前区域から
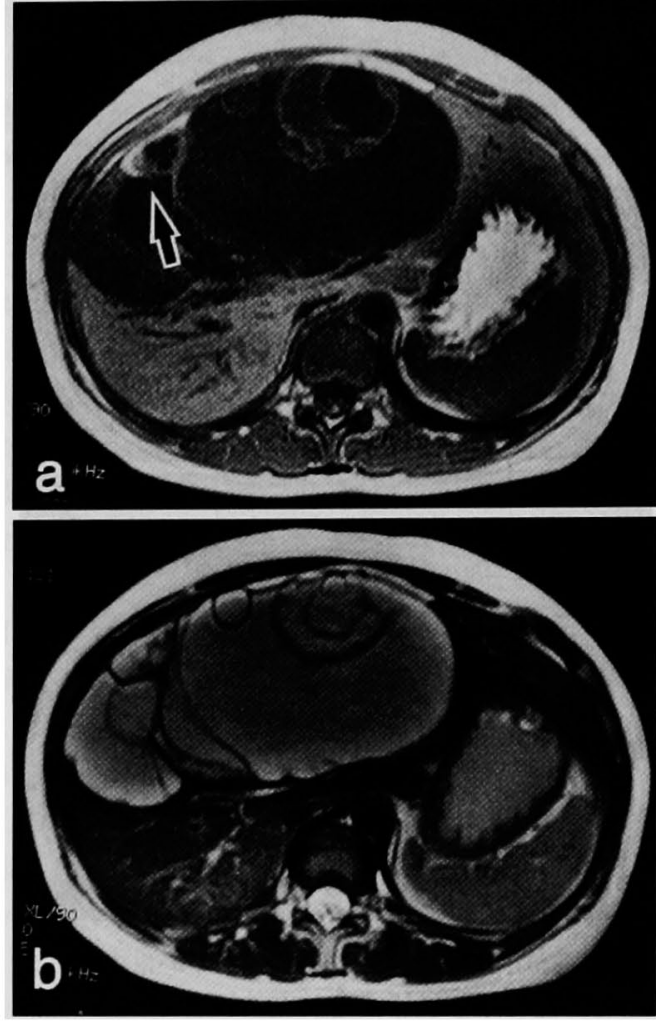

図 3 腹部 MRI 検査

a T1 強調画像：哄胞性腫罍内部は低信号を呈し ていたが一部は高信号であった（矢印）.

b T2 強調画像：噻胞性腫瘤内部は高信号を呈し ていた。

内側区域を占居し，肝外にも著明に発育した巨大な竞 胞性病変を認めた (図 5 a ). 肝の授動および肝門部の 確認，処理が困難であった為，まず震胞壁にタバコ縫 合をかけ内容液を穿刺吸引した，淡黄色の粘液性の内 容液1.61 が吸引され, 肝の授動が可能となり肝中央 2 区域を占める腫瘍全体を含めて肝部分切除，胆咅摘出 を行った。雚胞の割面に明らかな充実性部分はなく， 迅速病理診断でも悪性所見は認められなかった。衰胞 内容液の細胞診は class 1であったが, 腫瘍マーカーは CEA 335ng $/ \mathrm{ml}$, CA19-9>10,000U $/ \mathrm{ml}$ と高値であっ た.

摘出標本：径 $21 \times 15 \times 6 \mathrm{~cm}$ の蒦胞性腫場であり, 割面では多数の隔壁を有していたが充実性部分は認め られなかった（図５ｂ）。

病理組織学的所見：荛胞壁は一層の粘液産生を示す 円柱上皮で被覆され，一部で核の重層化，乳頭状增殖 をみるも極性は保たれ核異型も軽度であった（図 6 

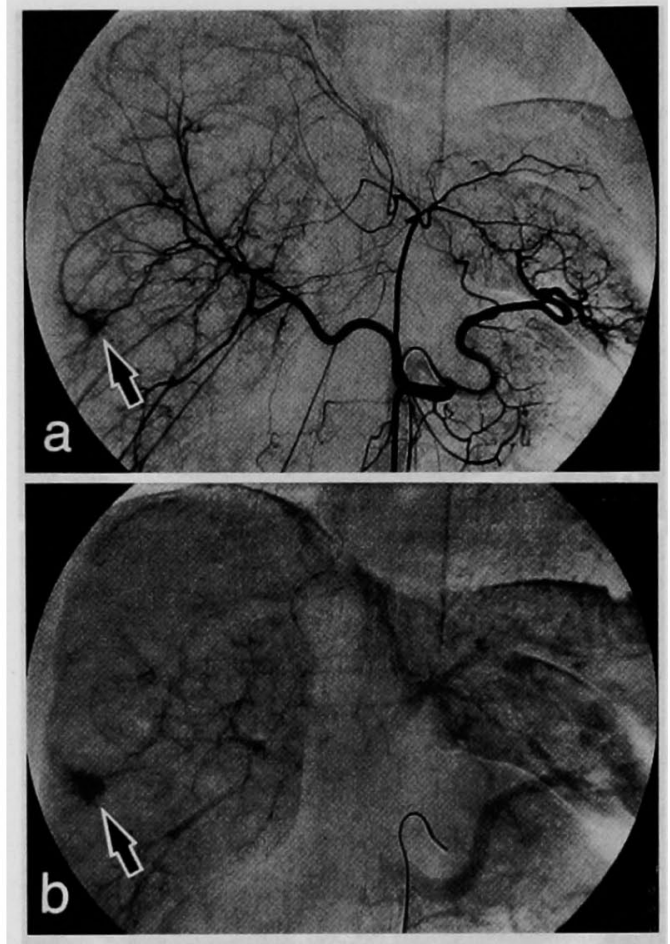

图 4 腹部血管造影：a）肝門部を中心に血流の乏 しい巨大な腫瘍がみられ, 右外側辺縁部に浱染像 が認められた (矢印). b ) 門脈の本幹, 左右の一 次分枝は腫場により圧排され不明瞕であり，右外 側辺縁部に湮染像が認められた（矢印）。

a ).上皮下の間質には卵巣間質類似の紡鍾形細胞の増 殖を認めた (図 $6 \mathrm{~b}$ ). 以上より肝衰胞腺腫と診断され た. 免疫染色検查に扔いて上皮成分では CEA(一), CA19-9(+), 間質成分て は vimentin $(+), \alpha$ SMA $(+), \operatorname{ER}(-), \operatorname{PgR}(-)$ であった。

術後経過：良好で術後14日目に退院となった。平成 17年 9 月現在, 再発の徴候は認めていない.CA19-9は $16 \mathrm{U} / \mathrm{ml}$ と正常化している.

\section{考 察}

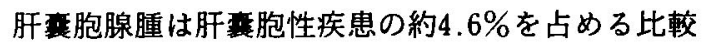
的稀な疾患で中年女性に多いとされており2)，近年の 画像診断の進歩によりその報告例が增えてきている。 本症は腹部膨満感, 腫㾇触知など大きな腫瘤に起因す

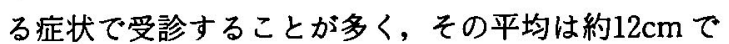
あったとしている ${ }^{3)}$. 自験例も同様であり, 来院時は腹 部膨満感と腹痛を訴えており歩行も制限をうける状態 であった。

肝震胞性疾患の診断は超音波, CT, MRI などが有用
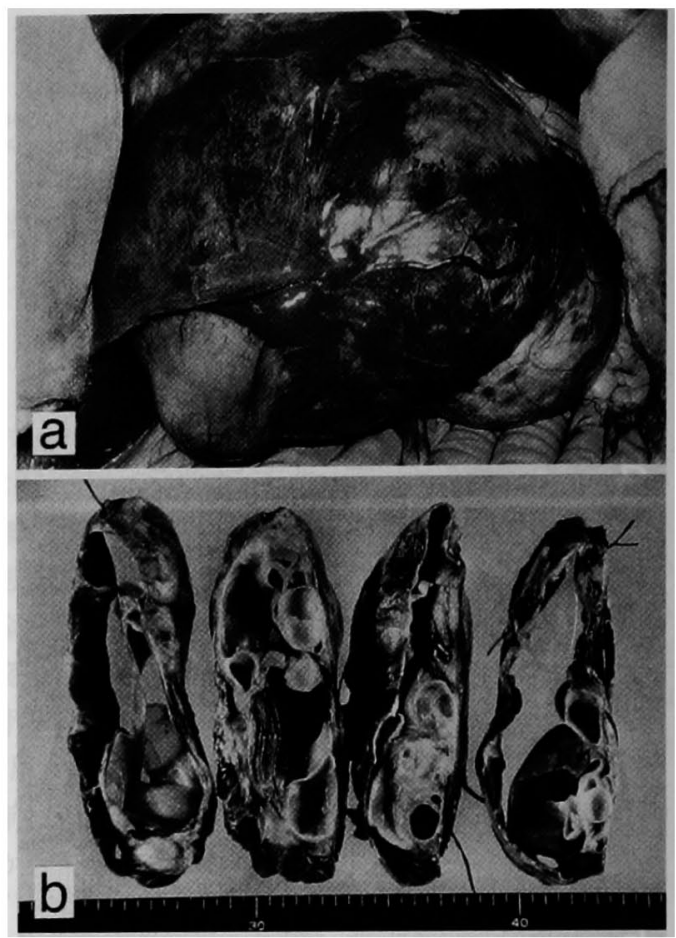

図 5 a 手術所見：丵胞は肝前区域および内側区域 から肝外に著明に発育していた。

b 摘出標本 (割面)：多数の隔壁を有していた が充実性部分は認められなかった。

とされている．単房性で壁が平滑であれば単純性書胞 と診断可能であり，多房性で壁に充実性成分や乳頭状 隆起が証明される場合には塞胞腺腫や塞胞腺癌が疑わ れる31-6). また MRI では出血した蘘胞は T1強調画像 で著しい高信号を示し, 通常の襄胞とは鑑別が出来 $3^{6)}$. 血管造影では充実性成分や隆起性病変に濃染像, 新生血管，血管壁の不整がみられることが癌の特徴と の報告もある7). しかし，一般的に術前に肝亮胞腺腫と 肝蓑胞腺癌を鑑別することは困難とされており，また 肝辜胞腺腫は癌化の potential を有しているとされ腺 腫から腺癌への移行例の報告もあり, 肝哓胞腺腫と肝 毫胞腺癌は一連の疾患として取扱う必要がある ${ }^{18)}$ 。 ま た霓胞壁の針生検や内容液の細胞診は偽陰性の可能性 があり，覀性であれば播種を起こす可能性もあり安易 な第刺は避けるべきであるとされている314)，自験例て はCTで多房性肝辜胞の隔壁が造影されるのみで明ら かな充実性成分は認められなかったが, MRI では T1 強調画像で一部が高信号を呈し出血が疑われ, 肝動脈 造影にて亯胞の辺緑部に濃染像があり悪性の可能性も 


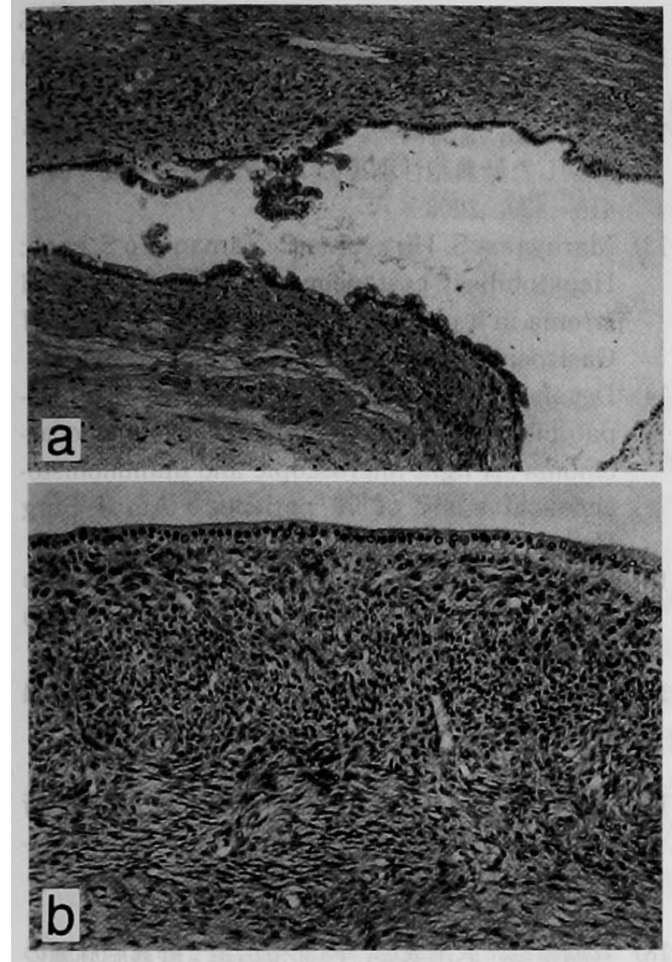

図 6 病理組織学的所見：a）壁は粘液産生を 示す一層の円柱上皮で被覆され，核異型も軽度て あった $(\mathrm{HE}$ 染色, $\times 40)$ 。 b ) 上皮下の間質には卵 巣間質類似の紡鍾形細胞の増殖を認めた（HE 染 色, $\times 100$ )。

示唆された．結果的に切除標本では粘液のみであり充 実性部分を認めることはできず，肝動脈造影による濃 染像も肥厚した咅胞壁などが考えられた。

病理組織学的な検討から，1985年にWheeler らが 紡鏵形細胞からなる間葉系間質を有する肝雍胞腺腫 17 例を報告し cystadenoma with mesenchymal stroma (CMS) という疾患概念を提唱した．組織学的には囊 胞壁の細胞は円柱あるいは立方上皮で粘液産生である こと, 密な紡鍾形の細胞で構成される間葉系間質を伴 うことが特徴としている。この間質は卵巣の間質に類 似しており, ovarian-like stroma と呼称されている. さらに以前に報告された肝跤胞腺腫34例を検討し， CMSの基準を満たした27例は全例女性に発生してお り平均年齡が44.1藏と若く，CMSの基準を満たさな い7例では 5 例が男性で平均年齢も53.4歳と高く臨床

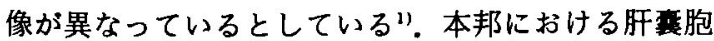
腺腫の報告は1983年の沖本ら”の報告以降2005年の鈴 木ら ${ }^{10)}$ の報告までに検索しえた限りでは自験例を含め
て56例であり，男性13例 (23.2\%)，女性43例 (76.8\%) と女性に多かった。そのうち畉巣様間質が認められた

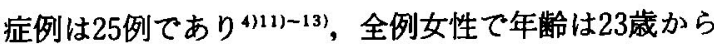
79歳に及び，平均年齢は51.4歳とWheeler ら"の報告 より高齢であった，CMS 報告例は全例女性であるこ とより女性ホルモンの影響が示唆されているが8), 自 験例ではホルモンレセプターは ER, PgR 共に陰性で あった.また, Devaney ら ${ }^{14)}$ は肝蒦胞腺癌14例の予後 を検討し卵巣様間質を伴った 5 例は 4 〜 年の経過て 全例生存していたが，卵单様間質を伴わない 9 例中 7 例は死亡していたことから卵巣様間質を伴う症例は予 後が良好な疾患であるとしている。

腫瘍マーカーに関して血中 CA19-9は悪性疾患の有 用なマーカーであるが肝萣胞腺腫でも上昇することが 指摘されている4．従って上昇していても悪性の根拠 にはならず,むしろ治療効果の判定に用いられている. 自験例でもCA19-9は術前には高值であったが術後は 正常になっていた。裹胞夜中のCA19-9に関しては肝 軎胞腺腫, 腺癌共に高值を示すことが多く, CEAにつ いても肝襄胞腺腫, 腺癌では高值を示す傾向があり, これらの腫瘄マ一カーで良悪性の鑑別は困難であると

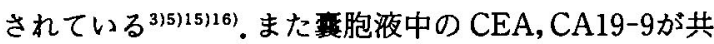
に高值を示している肝婁胞腺腫は malignant potential が高いとしている(15)，自験例においても亯胞液中 のCEA，CA19-9は共に高值を示していたが悪性所見 は認められなかった。

肝霓胞腺腫の治療については外科手術が基本である が開空術後に癌化した例もあり ${ }^{17}$, 開空術, 部分切除に 終わることなく禀胞を含めた肝切除が必要であ $3^{4(8) 18)}$. 自験例では襄胞の最大径が約 $21 \mathrm{~cm} て ゙$ 肝外に も著明に発達しており肝の授動, 肝門部の確認が困難 であったので内容液の穿刺吸引を行った。軎胞が巨大 で授動が困難な場合は内容液吸引をまず最初に行う場 合もあり ${ }^{19)}$ ，覀性の可能性も考之内容液の腹腔内人の 流出を十分に予防することが必要である。また肝亯胞 腺腫は肝囊胞腺癌との鑑別が術前には困難であること より術中の迅速病理診断が必要であり手術術式，リン パ節郭清の範囲についても十分に検討しておくことが 必要と考えられる。

結語

卵单様間質を伴った巨大な肝襄胞腺腫の 1 例を経験 したので報告した，肝䨖胞腺腫は肝薱胞腺癌との鑑別 が困難で悪性化の報告もあり，積極的に手術を行い異 胞の完全な切除が必要である。 


\section{文献}

1) Wheeler DA, Edmondson HA: Cystadenoma with mesenchymal stroma (CMS) in the liver and bile duct. Cancer $15: 1434-1445,1985$

2) Lee JH, Chen DR, Pang SC, et al: Mucinous biliary cystadenoma with mesenchymal stroma : Expression of CA19-9 and carcinoembryonic antigen in serum and cystic fluid. $J$ Gastroenterol $31: 732-736,1996$

3）野村 尚, 布施 明, 軽部康明他：著明な肝外発 育を呈した肝谸胞腺腫の 1 例。 日臨外会誌 64 ： $153-158,2003$

4) 谷口健次, 桐山幸三, 和田応樹他：畉巣様間質を 伴う肝襄胞腺腫の 1 例. 日臨外会誌 $64: 2554-$ 2558,2003

5）小森山広幸, 㮩本武治, 田中一郎他：肝素胞腺腫 の 1 例. 日臨外会誌 $61: 1848-1852,2000$

6) 岡田吉隆, 大友 邦: 肝真胞性病変一画像と病理, 蕉胞腺腫 - 堡胞腺癌。消画像 $5: 89-93,2003$

7) 小久保宇, 古井 滋, 大友 邦他: 肝莫胞腺腫 腺癌の画像診断. 臨放線 $30: 549-554,1985$

8）飯田 拓, 山際健太郎, 八木基太郎他：卵栄様間 質を伴った肝素胞腺腫の 1 切除例. 日消外会誌 $36: 106-111,2003$

9）沖本俊明，長田栄一，井川澄人他：尾状葉上り発 生した肝裳胞腺腫の 1 治験例. 臨外 $38: 1371$ 1375,1983

10）鈴木裕之, 諏訪敏一,山下純男他：肝婁胞として 経過観察中 9 年目に画像上咅胞内の形態変化を示
した肝要胞腺腫の 1 例. 外科 $67: 234-237,2005$

11）北湯口広, 林田典子, 福神浩兼他：肝㩰胞腺腫の 1 例. 旭中病医報 $18: 12-16,1996$

12）蔵原 弘, 上野真一, 塗木健介他：長期の経過を 観察した肝童胞性腫瘍の 2 例. 日臨外会誌 64 ： $416-420,2003$

13) Maruyama $S$, Hirayama $C$, Yamamoto $S$, et al : Hepatobiliary cystadenoma with mesenchymal stroma in a patient with chronic hepatitis C. J Gastroenterol 38:593-597, 2003

14) Devaney K, Goodman ZD, Ishak KG: Hepatobiliary cystadenoma and cystadenocarcinoma : A light microscopic and immunohistochemical study of 70 patients. Am J Surg Pathol 18:1078-1091, 1994

15）立川大介, 稲田繁充, 古藤 剛他：曝胞液中の CEA，CA19-9が異常高值を示した肝竡胞腺腫の 1 例. 臨と研 $75: 2194-2197,1998$

16）佐々木洋，山田晃正，石黑信吾他：肝褰胞腺癌(腺 腫)の臨床, 画像, 病理. 外科治療 $85: 583-592$, 2001

17) 村上雅彦, 新井一成, 幡谷潔他: 肝蕉胞腺腫術 後経過中に発症したBiliary Cystadenocarcinoma の 1 例。日臨外会誌 $46: 1336-1343$, 1985

18）真鍋達也, 武田成彰, 阿部祐治他 : 肝喜胞腺腫の 3 例。 日臨外会誌 $62: 1002-1006,2001$

19）大澤武, 北川 晋, 野畸善成他：巨大肝蘘胞腺 癌の 1 例. 外科 $61: 1047-1051,1999$

\title{
A CASE OF HUGE HEPATOBILIARY CYSTADENOMA WITH OVARIAN-LIKE STROMA
}

\author{
Shinichiro MAKIMOTO, Masafumi TOMITA, Kazuki SAKAMOTO, \\ Masaya SHINBO, Akira HAYASHIBE and Takeshi NAKAMOTO \\ Department of Surgery, Kishiwada Tokushukai Hospital
}

A 35-year-old woman was seen at the hospital because of abdominal fullness and abdominal pain. Abdominal ultrasonography, computed tomography and magnetic resonance imaging detected a huge multilocular cystic tumor $21 \mathrm{~cm}$ in maximum diameter in the liver, showing a remarkable extrahepatic growth.

Angiography of the hepatic artery showed a tumor stain, and the serum level of CA19-9 was high, $247 \mathrm{U} / \mathrm{ml}$. The patient was operated on under a diagnosis of hepatobiliary cystadenoma or cystadenocarcinoma. The cystic tumor arose extrahepatically from the anterior and medial segments of the liver, and the tumor was resected completely. The resected specimen contained the multilocular cystic tumor, but no recognizable solid lesion was found. Histologically, the inner layer of the cyst was lined by a single layer of mucin secreting columnar epithelium, and the intermediate layer was composed of dense cellular mesenchymal stroma, so called ovarian-like stroma. Hepatobiliary cystadenoma with ovarian-like stroma was diagnosed. The high serum CA19-9 level was normalized after the operation.

Hepatobiliary cystadenoma and adenocarcinoma are difficult to distinguish before the operation. Since hepatobiliary cystadenoma is a rare neoplasm with possible malignant transformation, total resection of the tumor is recommended. 